\title{
Reasons for Hand Pulling Public Employees from Their Position and Judicial Oversight of the Decision to Pull Hand in The Iraqi and Jordanian Laws
}

\author{
Abdulwahhab Gumaah Al-Kubissi*, Shatha Ahmed Al-Assaf \\ Department of Law, Faculty of Law, Isra University, Jordan \\ *abd1963.ahmed1963@gmail.com
}

KEYWORDS: Hand Pull, Public Servant, Judicial Oversight, Iraqi Law, Jordanian Law.

Crossref doi https://doi.org/10.51345/.v32i2.254.g226

\begin{abstract}
:
This research focuses on the reasons for withdrawing the public employees hand from his position in the Iraqi and Jordanian Laws and judicial oversight over the decision to withdraw. He public employees. The research tries to answer a very important problem which is the extent of the legal regulation for the reasons for withdrawing the employees hand from the work of this job and the judicial: The first topic focuses on the reasons for withdrawing the public employees hand from his position. The second topic deals topic deals with judicial oversight of decisions to withdraw the employees hand from his position. A number: 1- that the administrative courts look into the penalties directed at the employee from the administrant to the employee who has withdrawn the hand from his public office. especially in the penalties of dismissal and dismissal, provided that the appeal is mandatory either by the employee or by investigative committee to raise all the investigative papers and the penalty directed to the employee to the administrative court consider whether the punishment is correct or not, the two penalties mentioned above are among the most serious penalties that are applied to the employee. 2- He suggested to the civil service system, setting time to suspend the year from work and not to be dismissed because in this it generates the state treasury and harms the public employee who is suspended from work to receive half of his salaries and does not provide any community service.
\end{abstract}


أسباب سحب يد الموظف العام من وظيفته والرقابة القضائية على قرار سحب اليد في القانونين

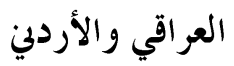

\author{
عبدالوهاب جمعة الكبيسي*، شذى أحد محمد العساف

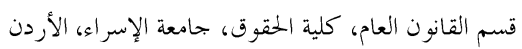 \\ *abd1963.ahmed1963@gmail.com
}

| سحب اليد، الموظف العام، الرقابة القضائية، القانون العراقي، القانون الاردين.

الكلمات المفتاحية

Crossref do

https://doi.org/10.51345/.v32i2.254.g226

ملخص البحث:

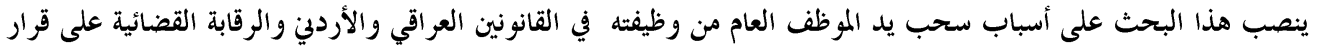

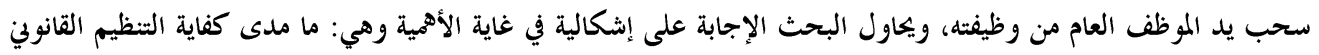

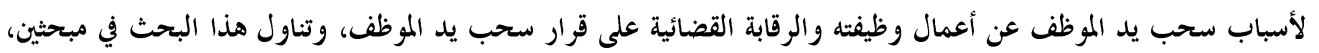

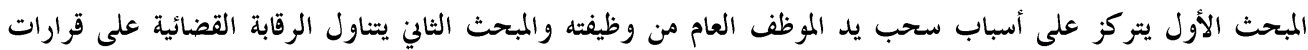

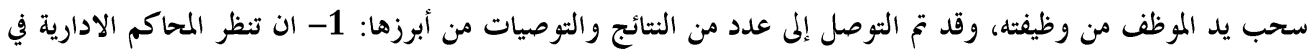

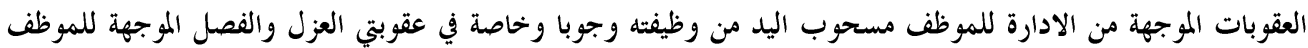

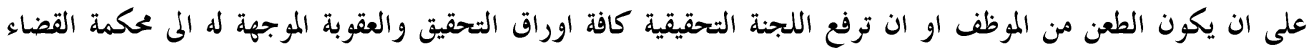

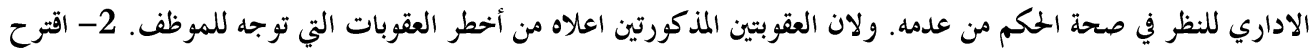

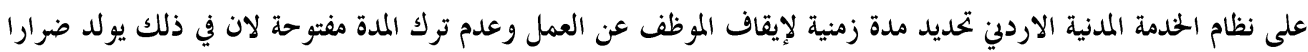
لحزينة الدولة وضرارا للموظف الموقوف عن العمل.

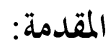

يكتاز التنظيم القانوني للوظيفة العامة والموظف العام بأهمية كبيرة، فالموظف العام هو الأداة التنفيذية

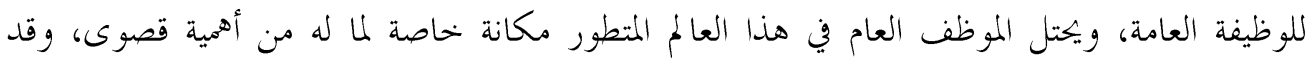
شرعت له قوانين لا سيما من أجل حمايته من التجاوزات التي من الممكن أن تؤثر على تنفيذ عمله

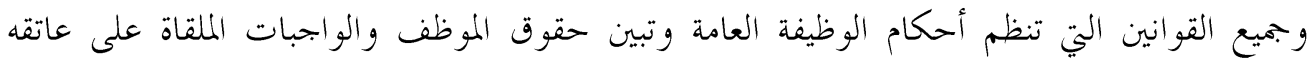

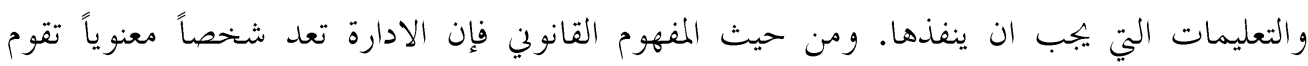

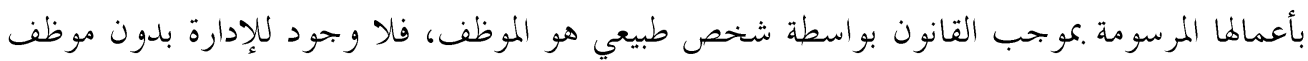


تقوم الدولة بتعينه وتصرف رواتبه من خزينة الدولة، لأن الموظف هو الأداة الفعالة لتسيير وتنفيذ مهام الدولة، ولكي تقوم الإدارة بنشاطاها يجبب أن تقوم بوضع قواعد قانونية وتعليمات خاصة لكي تنظم الأمور المتعلقة بالموظف العام. فالمشرع العراقي والمشرع الأردلي عد الوظيفة العامة أمانة مقدسة وخحدة اجتماعية للدمة المواطن والمجتمع تحكمها القيم الدينية والوطنية والقومية للحضارة العربية. فإذا ارتكب الموظف مخالفة بكق وظيفته أو ارتكب جريمة جنائية فإنه يكون في موضع شك بالنسبة للإدارة بأن استمراره في الوظيفة العامة قد يشكل ضرراً على المصلحة أو على اجراءات التحقيق أو يضر بالموظف نفسه. هلذه الأسباب دفع المشرع في كثير من دول العالم إلى منح الإدارة حق اتخاذ بعض الاجراءات الاحتياطية بحق الموظف العام ومنها سحب يد الموظف العام من وظيفته، ومنح القضاء الاداري مراقبة هذه القرارات التي من الممكن ان تكون تعسفية بكق الموظف، والتي سنتطرق هلا في بكثنا عن أسباب سحب يل الموظف العام من وظيفته ورقابة القضاء الاداري على هذه القرارات لوضع حد لتعسف الادارة التي من الممكن أن يتعرض لما الموظف. ومن هنا تظهر إشكالية البحث: ما مدى كفاية التنظيم القانوني لأسباب سحب يد الموظف عن أعمال وظيفته والرقابة القضائية على قرار سحب يد الموظف؟ ولإججابة على هذه الإشكالية فقد تم تقسيم البحث إلى مبحثين يوضح المبحث الأول التنظيم القانوني لأسباب سحب يد الموظف العام من وظيفته في القانونين العراقي والأردلي، ويسلط المبحث الثاني الضوء على الرقابة القضائية على قرار سحب يد الموظف العام من وظيفته.

\section{المبحث الأول: أسباب سحب يد الموظف}

ما أن القانون لا يسمح للإدارة ان تتخذ أي إجراء قانوبي ضد الموظف العام كالعقوبة على سبيل المثال إلا وفق الأصول القانونية المرسومة هلا من قبل القانون فكيف بالإدارة أن تتخذ قرار خطير كقرار سحب يد الموظف العام من وظيفته، وخاصة وأن قرار سحب يد الموظف العام يكون مضراً بسمعة الموظف و سمعة عائلته، و كذلك يولد ضراراً مادياً لذلك الموظف.

ولأهمية قرار سحب يد الموظف العام من الوظيفة فقد خصص المشرع العراقي فصلاً كاملاً لسحب يد الموظف العام في قانون انضباط موظفي الدولة والقطاع العام رقم (14) لسنة 1991 المعدل، وذكر فيها الأسباب التي يجوز فيها للإدارة أن تسحب يد الموظف من وظيفته، وقيد الإدارة في ذلك والا يعد قرار سحب اليد باطل (وما بين على باطل فهو باطل). 
وسنترق في هذا المبحث إلى مطلبين وهي الأسباب التي بتعل الإدارة تستخدم صلاحياتا في سحب يد الموظف العام من وظيفته، وذلك للإجابة عن السؤال الآتي: ما هي الأسباب التي تؤدي إلى سحب يد بـ ليد الموظف؟

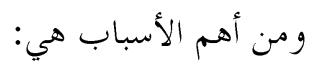

في حالة إحالة الموظف إلى لجنة تحقيقية نتيجة ارتكابه مخالفة مسلكية تستوجب التحقيق معه. في حالة احالة الموظف إلى القضاء المختص نتيجة ارتكابه جناية مخلة بالشرف.

ولذا سنخصص لكل سبب مطلب خاص به، وهما:

المطلب الأول: إحالة الموظف إلى لجنة تمقيقية. المطلب الثاني: إحالة الموظف إلى المحاكم المختصة.

\section{المطلب الأول: إحالة الموظف إلى لجنة تحقيقية}

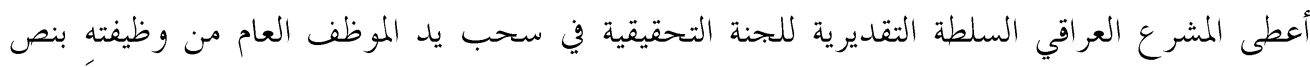

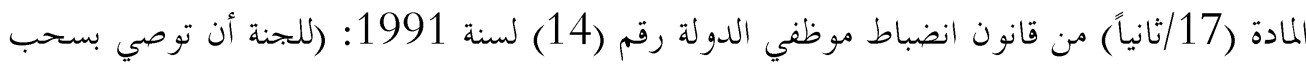
يد الموظف في أية مرحلة من مراحل التحقيق)؛ فيتضح من هذا النص أن المشرع العراقي قد أجاز للجنة أن توصي الجهة المختصة الذي لها صلاحية إحالة الموظف للتحقيق بسحب يده من من الوظيفة لحين انتهاء التحقيق.

وبناء" على ذلك فإن في حالة ارتكاب الموظف مخالفة مسلكية وتمت إحالته من قبل الجهة المختصة إلى اللجنة التحقيقية فليس من الضروري سحب يده من وظيفته، وإنما يمارس مهام وظيفته بالشكل الطبيعي إلا في حالة طلب اللجنة التحقيقية من الجهة التي أحالت الموظف للتحقيق بسحب يد وليد الموظف المحال عليها لغرض التحقيق معه. يرى الباحث أن استمرار الموظف بوظيفته اثناء إحالته إلى اللجنة التحقيقية وبالأخص إذا كانت احالته نتيجة مخالفة مسلكية ارتكبها في وظيفته فمن الممكن اذا لا تصل إلى الحقيقة؛ لأن ممارسة الموظف لمهام

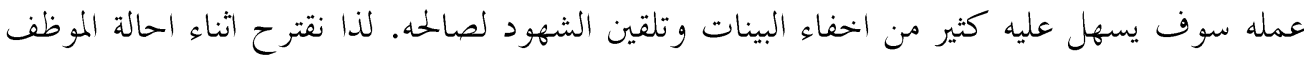
على اللجنة التحقيقية ايقافه وجوباً عن عمله ولو بصورة مؤقتة لحين ظهور توصيات اللجنة التحقيقية.

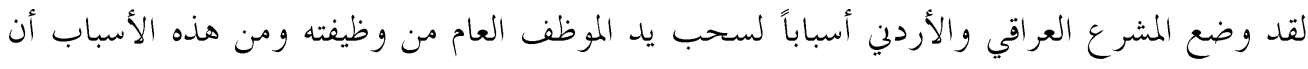

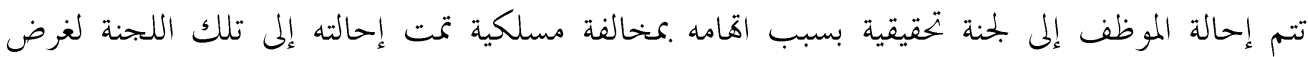

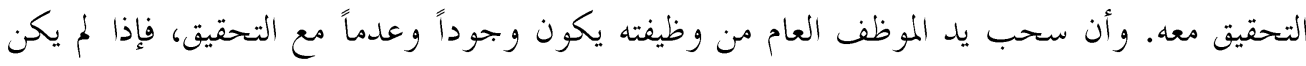


هناك تحقيق مع الموظف فلا يكون سحب يد للموظف حتى لو كانت سحب يده لأسباب منطقية أو مشروعة (1). نص القانون العراقي المادة (16) من قانون انضباط موظفي الدولة والقطاع العام رقم (14) لسنة 1991 المعدل على أنه يجب على الدائرة سحب يد الموظف العام من وظيفته طيلة فترة التوقيف وجاء

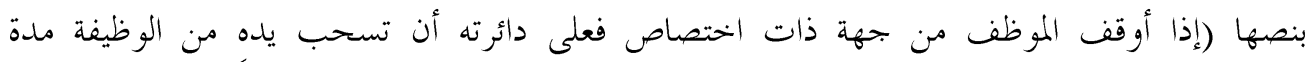
التوقيف). ولكن هنا يمكن اثارة السؤال الآتي: هل يجوز سحب دهب ديد الموظف العام من وظيفته في حالة اعتقاله من اي جهة مختصة؟ أن اعتقال الموظف العام يعد حالة استثنائية لأها تسلب إرادة الموظف من الحضور إلى مكان عمله وقيامه بأداء مهام واجباته الوظيفية خلال أوقات الدوام الرسمي وتشوبه حالات الاشتباه في كثير من الأحيان

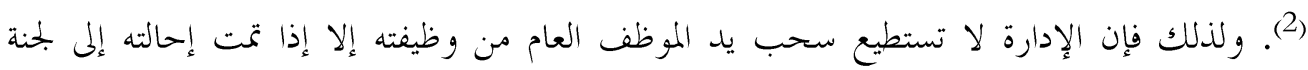

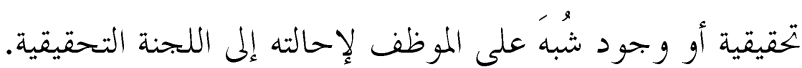

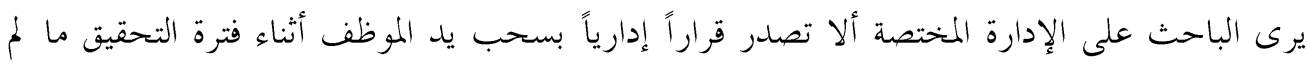

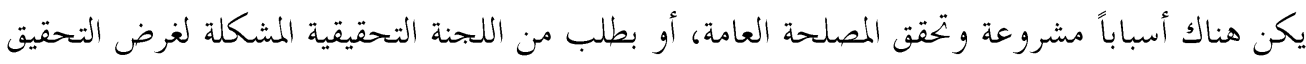

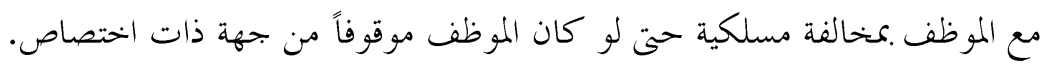

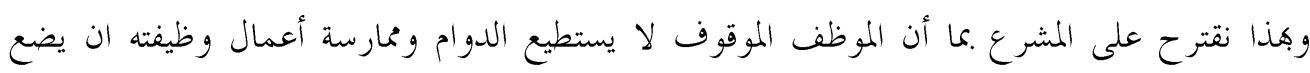

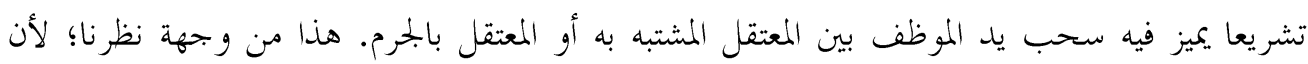

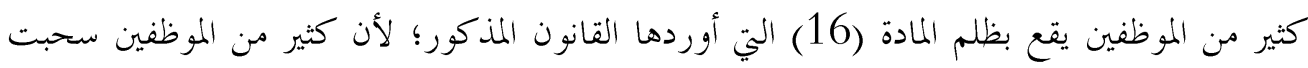

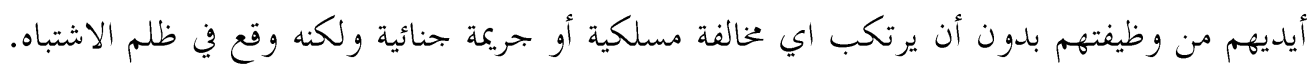

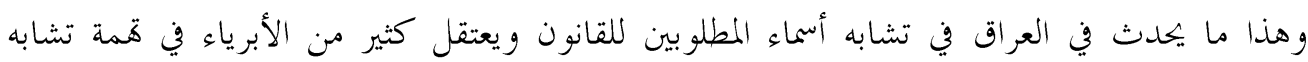
الاسماء. أما المشرع الأردلي فلم يعطِ لإدارة صلاحية ايقاف الموظف عن العمل دون أسباب قانونية أو حالات

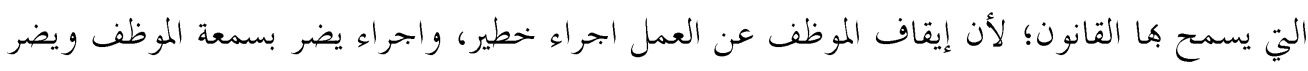

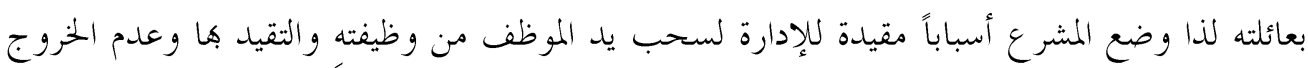

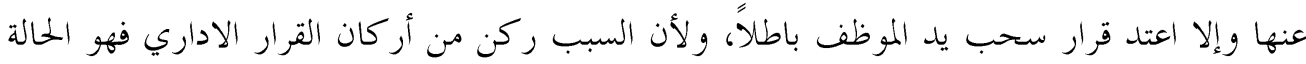
القانونية أو الو اقعية التي تحدث بعيداً عن جهة الإدارة قبل صدور القرار فتدفعها لاتخاذه(3). 
فنتيجة ارتكاب الموظف لأي مخالفة مسلكية سواء كانت المخالفة إيجابية أو سلبية تكون مخالفة القوانين و التعليمات التي تصدرها الدولة أو أخل بالمسؤولية الوظيفية أو الاساءة لها بسلو كه، فإنه يخضع للمسألة المهاء

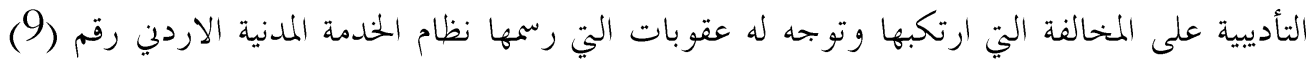

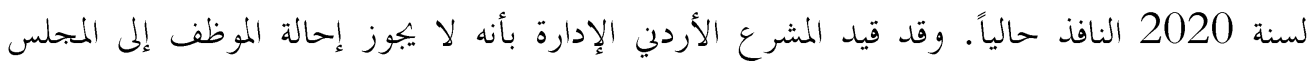
التأديي إلا بعد تشكيل للجنة تحقيقية على أن لا يقل عدد أعضائها عن ثلاثة أشخاص بمن فيهم رئيس

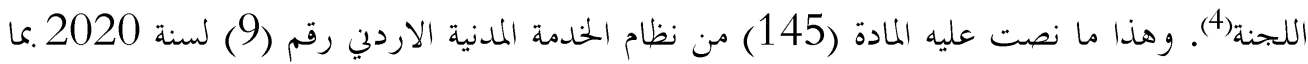
يلي: (إذا تبين لأي من الجهات المنصوص عليها في الفقرة (أ) من المادة (143) من نظام الخدمة المدنية

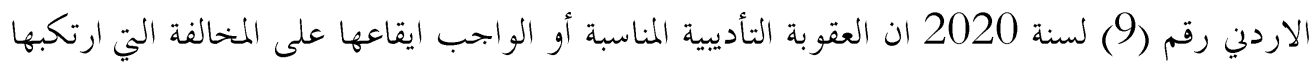
الموظف تزيد على العقوبة التي تمتلك صلاحية ايقاعها. فيترتب عليها رفعها مع بيان رأيها فيها إلى الجهة

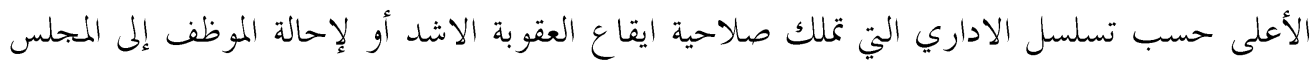
التأديي إذا رأت ذلك ضرورياً وفقا لأحكام هذا النظام)(5.). وتعد إحالة الموظف إلى المجلس التأديي من أسباب سحب يد المابد الموظف العام من وظيفته بنص المادة

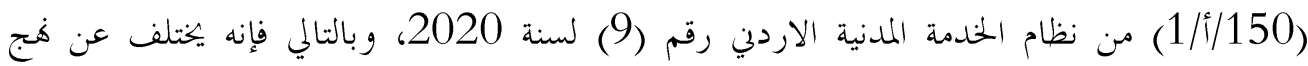
المشرع العراقي الذي أجاز في المادة (17) من قانون انضباط موظفي الدولة والقطاع الاشتراكي رقم

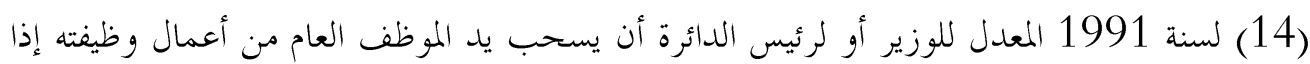
وجد أن بقاءه سيؤثر على سير التحقيق، كما أعطى للجنة التحقيق في المادة (18) منه الحق بأن توصي لمئي بسحب يد الموظف العام في أي مرحلة من مراحل التحقيق.

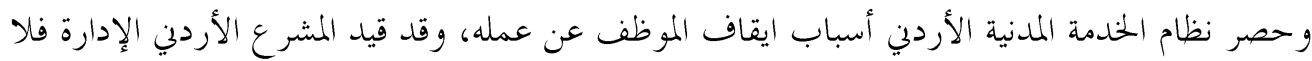
يمكن للإدارة أن تتجاوز هذه الأسباب لسحب يد الموظف، وإلا يكون قرار سحب اليد باطلاً؛ لأن

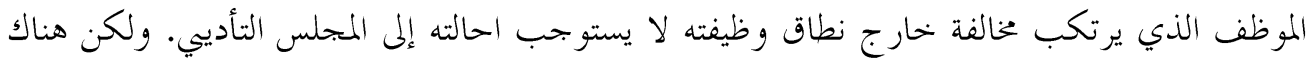

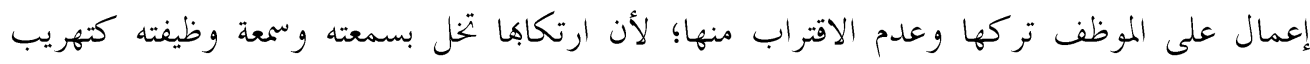

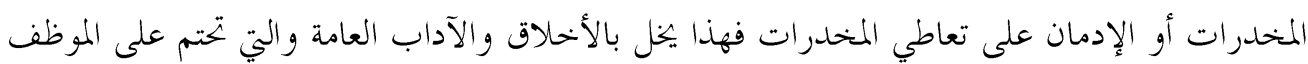

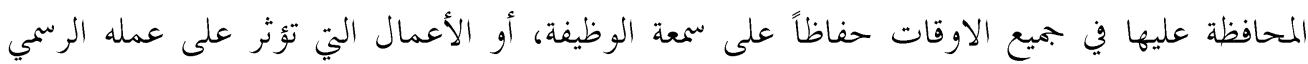

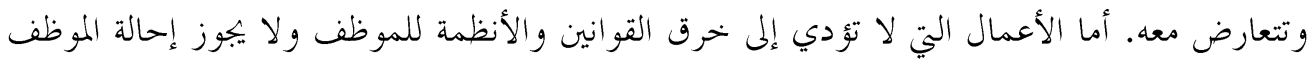

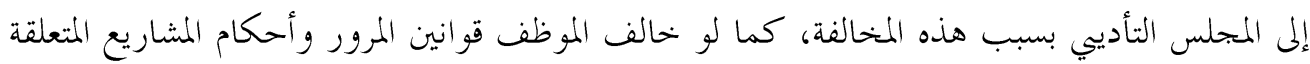

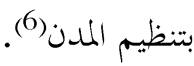


و تتم إحالة الموظف إلى المجلس التأديي بقرار من الوزير وهي ما ذكرته المادة (148/أ) من نظام الخلدمة

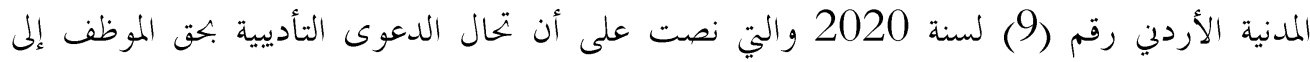
المجلس التأديي بقرار من الوزير مرفقة بما يلي:

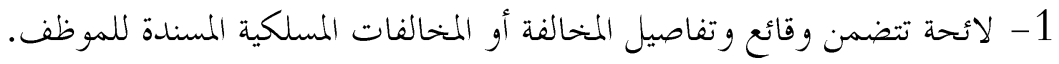
2- مخضر التحقيق الذي أجري حول تلك المخالفة أو المخالفات. 3- البيانات الخطية أو المادية في الدعوى. 4- اي وثائق أخرى يرى الوزير تقديمها للمجلس التأديي.

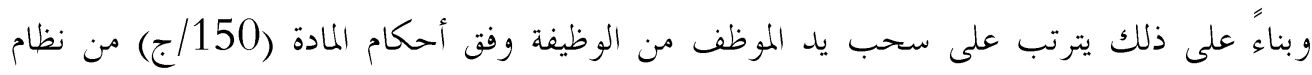

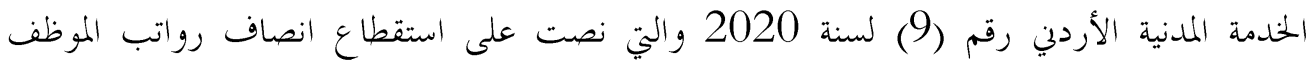
مسحوب اليد من وظيفته لحين البت في الدعوى المحال ها إلى المجلس التأديب.

\section{المطلب الثابي: إحالة الموظف إلى المحاكم المختصة}

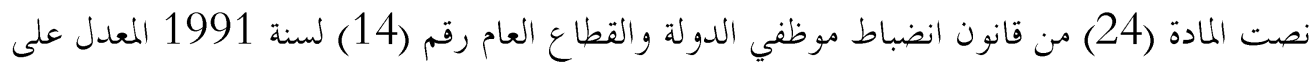

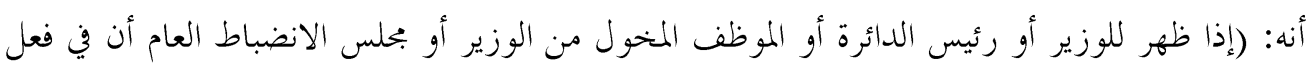

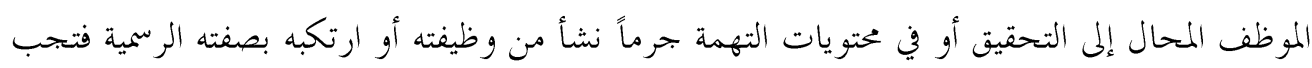
إحالته إلى المحاكم المختصة).

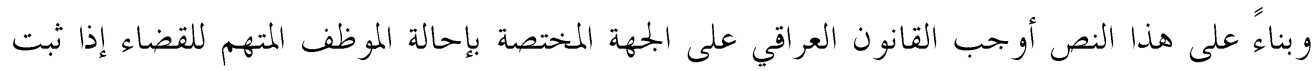

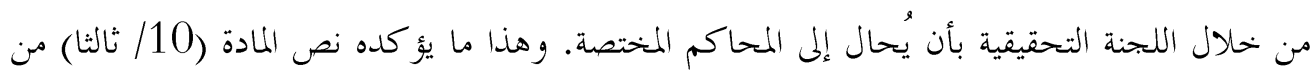
قانون انضباط موظفي الدولة رقم (14) لسنة 1991 بنصها (إذا رأت اللجنة أن فعل الموظف المحال

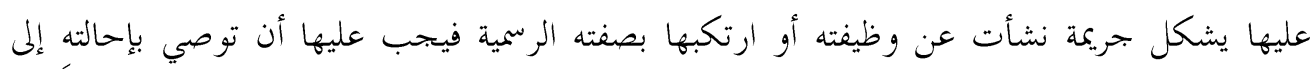

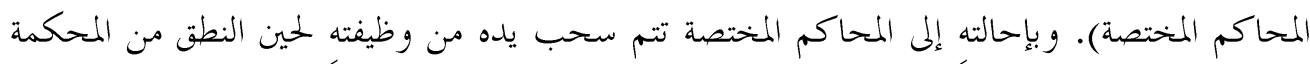

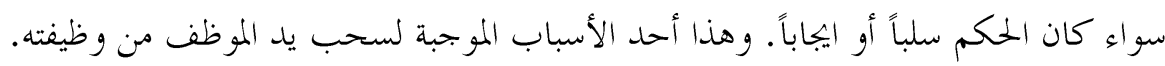

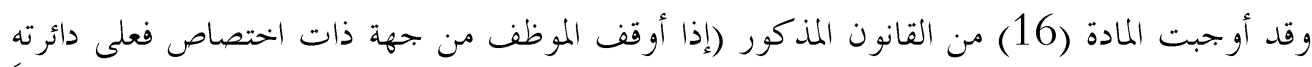

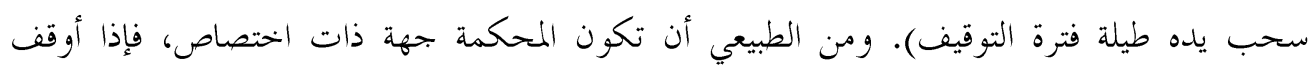
الموظف وأودع السجن نتيجة همة موجهة إليه أو شكوى مقدمة ضده، فمن الطبيعي تطبيق نص المادة (16) من القانون المذكور. 
اما في الأردن، فقد بينت أنظمة الخدمة المدنية الأردنية المتعاقبة ومنها نظام الحخدمة المدنية الحالي الأسباب التي تجعل الإدارة تمارس صلاحيتها في سحب يد الموظف العام في المادة (150/أ/ب) من نظام الخدمة

$$
\text { المدنية رقم (9) لسنة } 2020 \text { وهي: إحسي }
$$

أولاً: إحالة الموظف مقن من قبل دائرته إلى المحكمة لارتكابه مخالفة مسلكية أو جناية أو جنحة مخلة

إذا ارتكب الموظف مخالفة مسلكية ترتبط بجريمة جنائية أو جنحة مخلة بالشرف، فعلى الإدارة أو المجلس

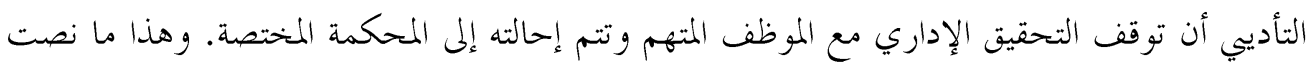

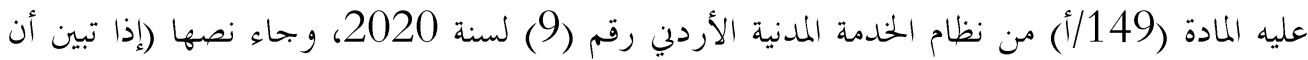
المخالفة التي أسندت للموظف تنطوي على جريمة جزائية. فيترتب إيقاف الاجراءات التأديبية وإحالة

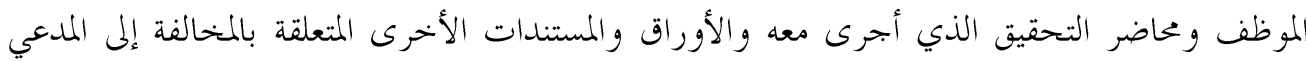

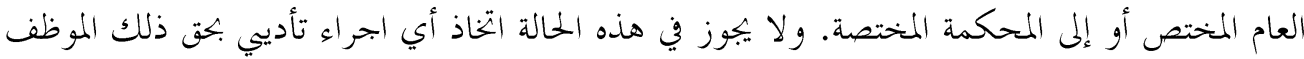

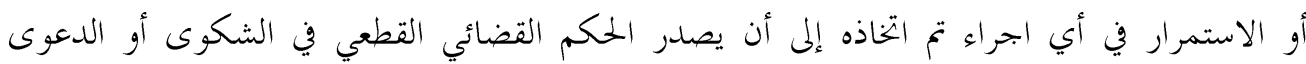

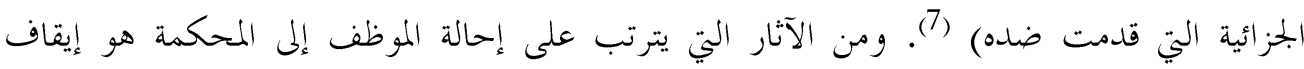

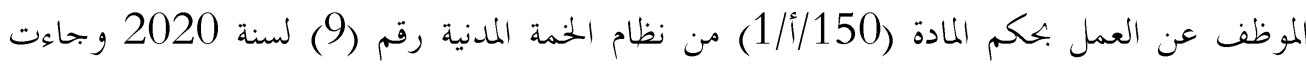
بالنص (يوقف الموظف عن العمل إذا تمت احالته من دائرته إلى المجلس التأديي أو المدعي العام أو رئمن

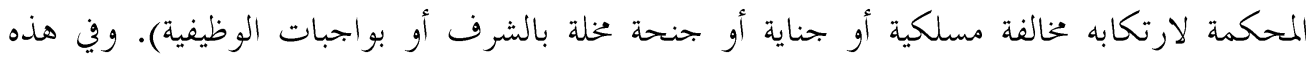
الحالة تصبح الإدارة لا سلطة هل على الموظف المحال إلى المحكمة لحين صدور حكم المحكمة بكق

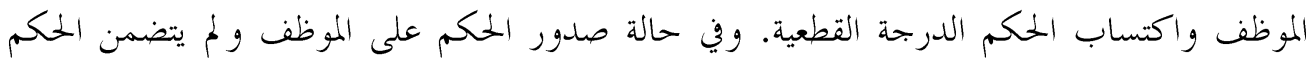
إدانته بما يؤدي إلى عزل الموظف، فقد نصت المادة (149/د) من النظام المذكور على أنه: (إذا كان

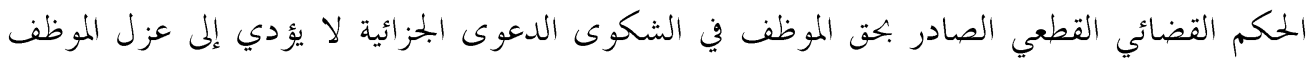
ورأى الوزير إحالته إلى المجلس التأديي فيستمر نفاذ قرار إيقافه عن العمل ويحال وفقاً لأحكام هذا لها

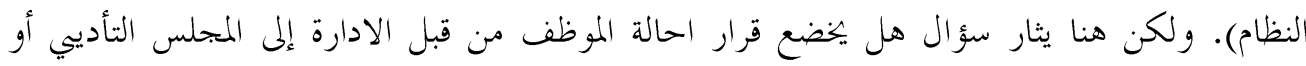

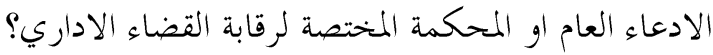

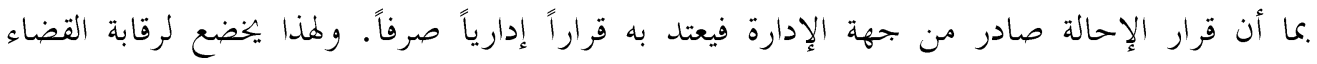
الإداري. وأن قرار الإحالة إلى المجلس التأديي أو المدعي العام أو المحكمة المختصة خاضع للطعن أمام المحكمة الإدارية الاردنية. إذ أن قرار الاحالة قرار اداري هائي ويجوز بهائه الطعن امام القضاء الاداري. 
وقد جاء في حكم سابق لمحكمة العدل العليا في قرارها المرقم (242/ 1994) (عند إحالة الموظف إلى

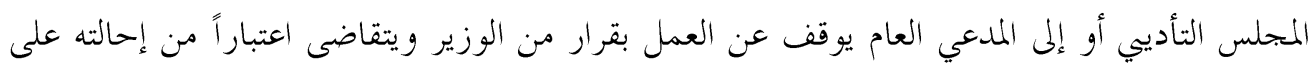

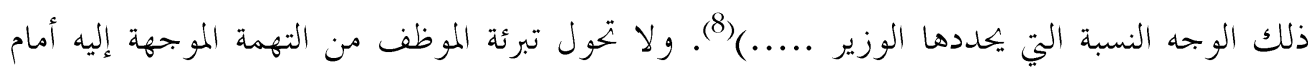

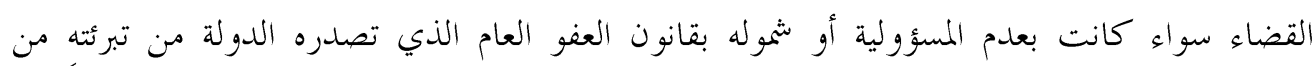

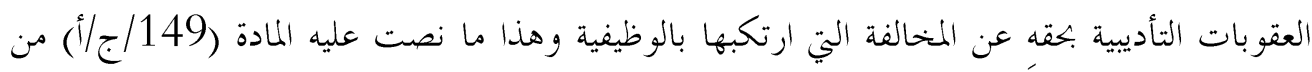

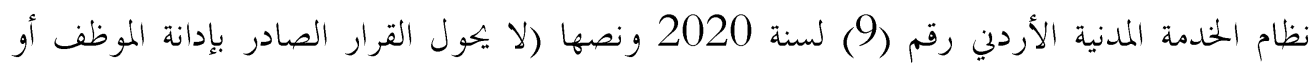

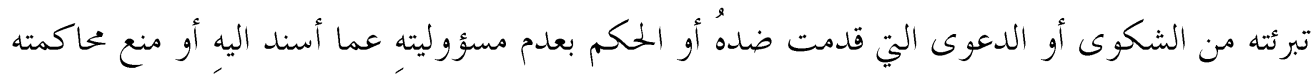

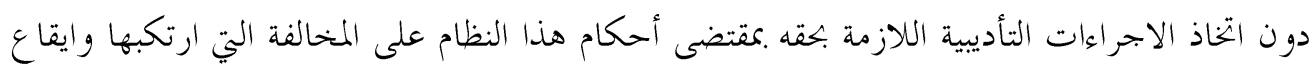

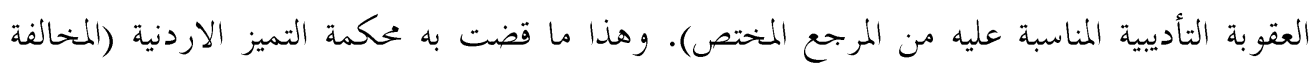

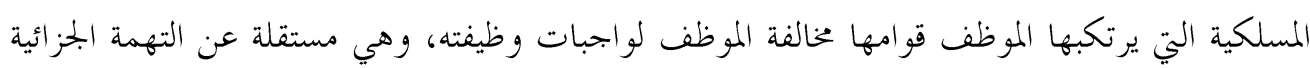

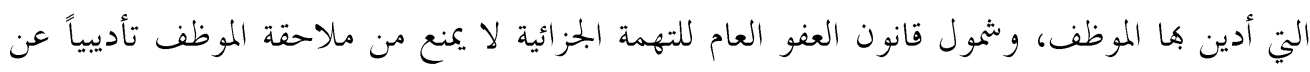

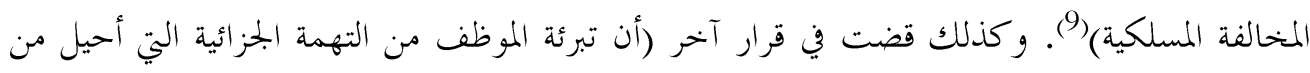

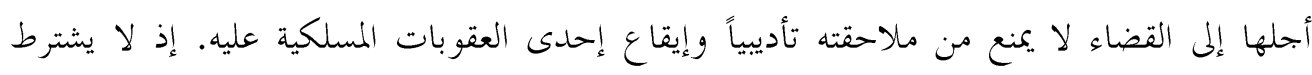

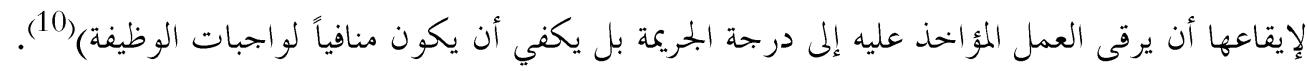

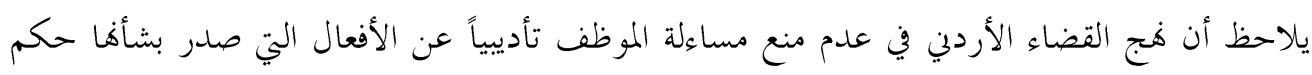

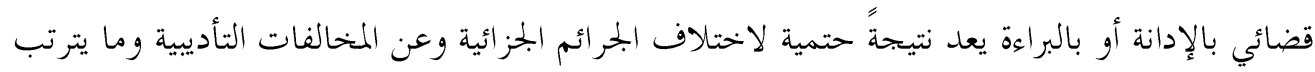

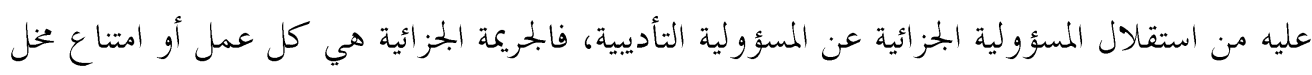

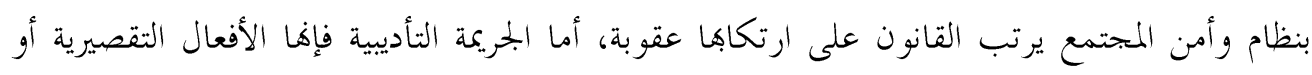

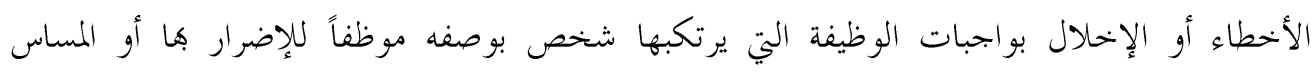

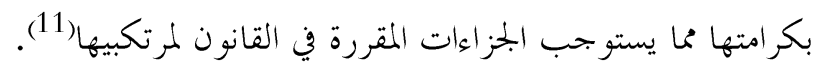

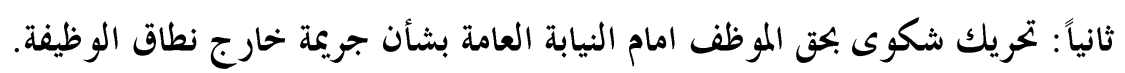

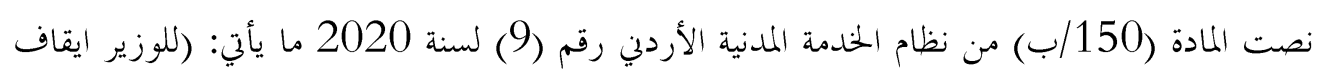

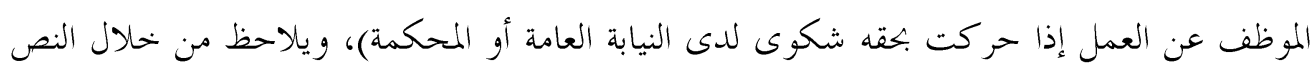

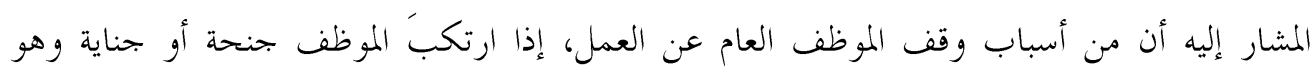

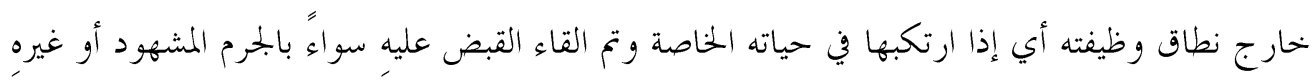

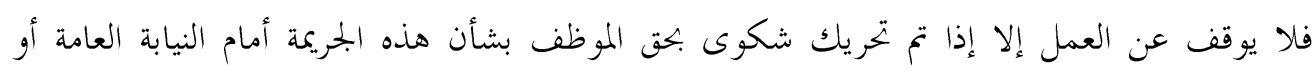


المحكمة، ففي هذه الحالة فإن للوزير أن يوقف عن العمل الموظف وفق المادة (150) من نظام الخخدمة

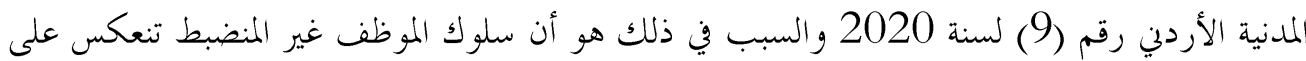
سلوك الموظف في دائرته ويصبح موظفاً غير موثوق فيه من دائرته ؛ لأن من الممكن أن تؤدي حاجته الماسة للمال من أجل صرفها في تعاطي المخدرات أو لعب القمار يجعله لقمة سائغة عند أصحاب المصالح

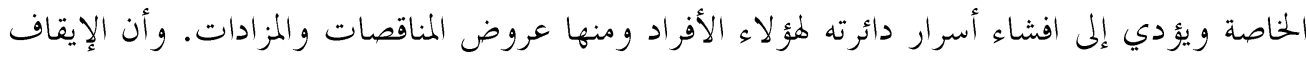
عن العمل لا يُعني فصل الموظف أو عزله من وظيفته أو قطع الرابطة القانونية بوظيفته، وإنما هو اجراء إداء احتياطي تتخذهُ الادارة كما ذكرنا سابقاً. ونصت المادة (149/أ) من نظام الخدمة المدنية الاردني رقم (82) لسنة 2013 وذكر الحالات التيت يوجب ايقاف الموظف عن العمل ففي حالة احالة الموظف إلى المجلس التأديبي أو المحكمة لارتكابه

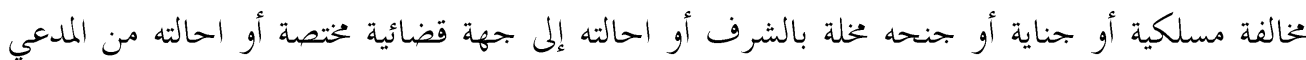

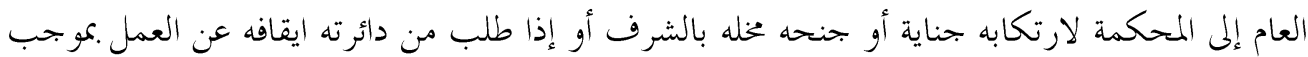
أي قانون آخر.

ففي هذه الحالات المذكورة اعلاه يكون ايقاف الموظف عن العمل وجوباً، وهذا ما أكدته محكمة العدل العليا الأردنية في قرارها رقم (471/ 1998): (احالة المستدعين إلى المدعي العام من قبل المستدعي ضده يتفق وأحكام النظام؛ لأن كف اليد هو أمر وجوبي وهو من صلاحيات الوزير سواء بطلب من

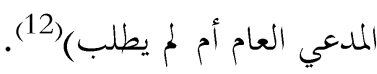
ولكن واستثناءً مما ورد في نظام الحندمة المدنية، فإن المشرع الأردلي في قانون الجرائم الاقتصادية منح السلطة التقديرية للنيابة العامة والمحكمة المختصة وقف الموظف من العمل إذا كان مرتكب جريمة

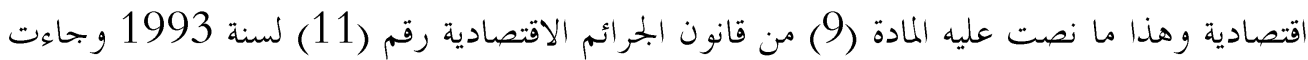
(كف يد مرتكب الجريمة الاقتصادية عن العمل إذا استدعت الضرورة ذلك وللمدة التي ترتئيها النيابة العامة أو المحكمة وحسب مقتضى الحال)(13). وأعطى المشرع الأردلي في قانون هيئة التزاهة ومكافحة الفساد لمجلس الهيئة صلاحية الطلب من الجهات

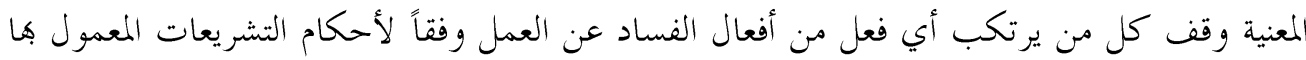

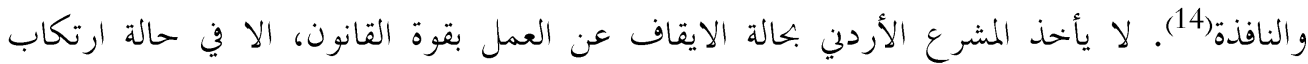
الموظف أي فعل من الأفعال الذي يجرمه القانون، وتم إيداع الموظف السجن احتياطياً فيوقف عن العمل 
إلى حين انتهاء التحقيق وإذا تمت إحالته من المدعي العام إلى المحكمة المختصة. ففي هذه الحالة يوقف عن العمل وفق المادة (150) من نظام الخحدة المدنية الأردني رقم (9) لسنة 2020.

\section{المبحث الثالي: الرقابة القضائية على سحب يد الموظف}

الرقابة القضائية على القرارات الإدارية هي ضمان لمنع تعسف الإدارة وتسرعها في التخاذ القرار الإداري.

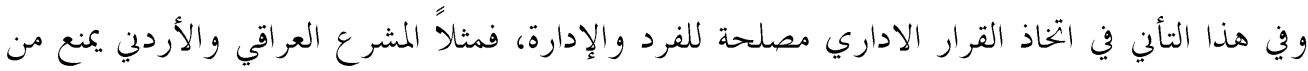
توجيه أي عقوبة للموظف إلا بناءً على توصيات لجنه تحقيقية أو استجواب، كما يتم السماح للموظف فئف

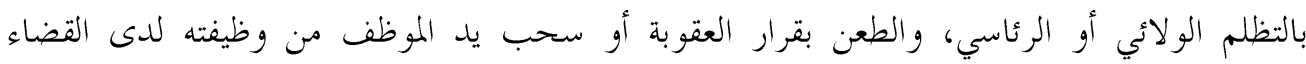
الإداري، مما يوفر ضمانات للموظف العام. لمان. والرقابة القضائية تعني إسناد سلطة الرقابة على أعمال الإدارة إلى القضاء. وتعمل هذه الرقابة على كفالة

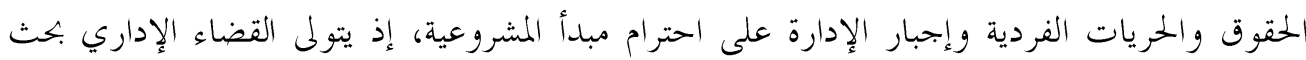
مشروعية تصرفات الإدارة بناءً على طعن يقدم من ذي مصلحة. فالرقابة القضائية لا تتم تلقائياً من جانب القضاء الإداري، بل عن طريق طعن قضائي يأحذ صورة الدعوى(15).

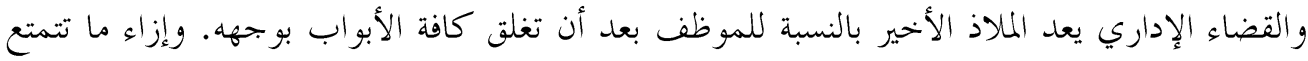
به الإدارة من سلطة تقديرية واسعة في اصدار قرار سحب اليد والآثار الكبيرة التي تترتب بسببه على التى حياة الموظف فإن الضمانة القضائية تكون الدرع الواقي أمام تعسف الإدارة في القرارات التي تصدرها ضد الموظف، وذلك بتمكين الموظف من الطعن بالقرار الإداري الصادر من الإدارة. وهنا يثور السؤال

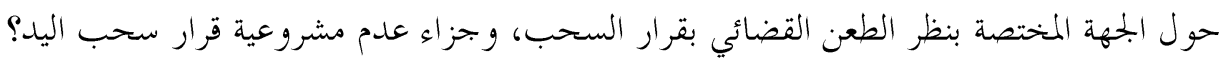
سنحاول الإجابة عن هذا السؤال في المطلبين التالين: المطلب الأول: الجهة المختصة في النظر بالطعن في قرار سحب يد الموظف العام من وظيفته المطلب الثاني: جزاء عدم مشروعية قرار سحب يد الموظف العام من وظيفته

\section{المطلب الأول: الجهة المختصة في النظر بالطعن في قرار سحب يد الموظف العام من وظيفته}

الجهة المختصة بالرقابة على القرارات الإدارية هي محكمة القضاء الإداري وبحلس الانضباط العام ويخضع

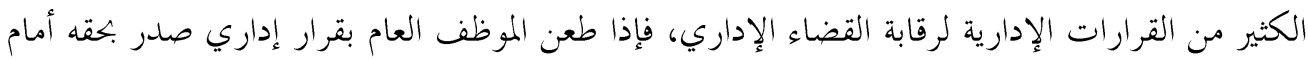
القضاء المختص و أفضى الفحص إلى عدم مشروعيته أي وجود عيب فيه فللقاضي أن يصدر قرار بإلغاء 
القرار الإداري، وإلغاء القرار الإداري من قبل القضاء الإداري لا يمكن أن يكون إلا بأثر رجعي فهو

$$
\text { هدم القرار من تاريخ إصداره(16). }
$$

إن تحديد السلطة المختصة بالنظر في الطعن بقرار سحب يد الموظدف يترة يتطلب الوقوف على الطبيعة القانونية لهذا القرار ومعرفة ما إذا كان القرار إدارياً أم لا؛ ولأن موضوع درعة دراستنا دراسة مقارنة بين القانون العراقي والقانون الأردني، فسنركز على هذه الدراسة ونتطرق إلى مواقف بعض القوانين العربية لغرض الاطلاع عليها. الفرع الأول: الجهة المختصة في نظر الطعن بقرار سحب اليد في القانون العراقي موضوع سحب يد الموظف العام من الفقه والقضاء العراقي حقه و لم يعطه إلا القليل. وأن المشرع العراقي لم يذكر في القوانين الانضباطية الجهة التي يمكن الطعن لديها في القرار الإداري الصادر من

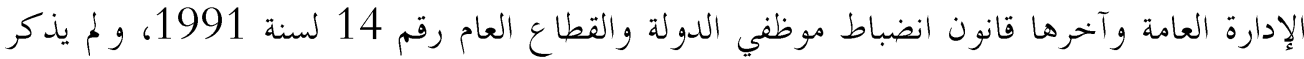

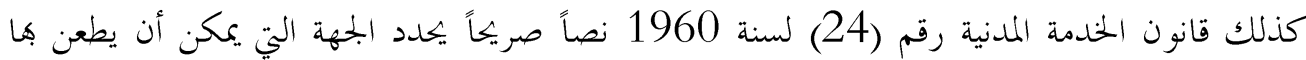
الموظف التي يصدر بحقه قرار سحب يده من الوظيفة العامة.

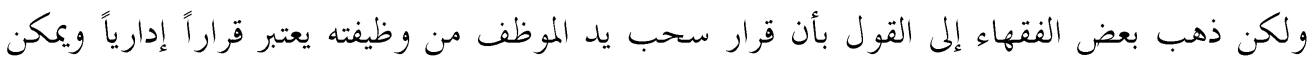

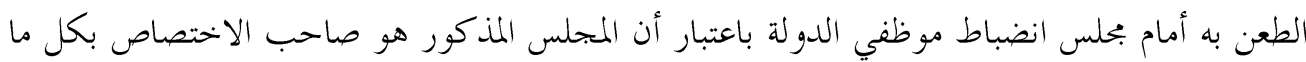

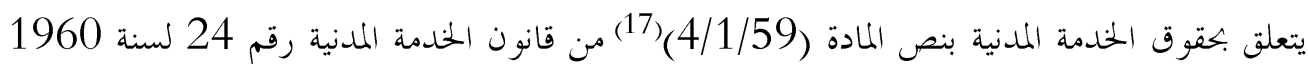
المعدل. و التي نصت الفقرة (1) فيه (لا تسمع في المحاكم الدعاوى التي يقيمها على الحكومة الموظف أو لئه

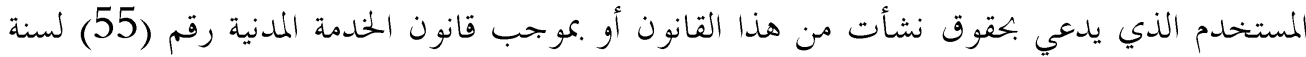

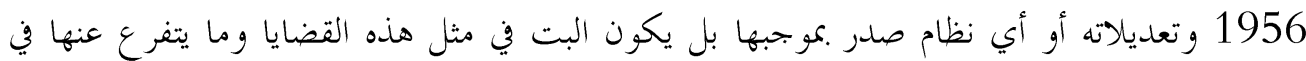
بحلس الانضباط العام). ونصت الفقرة (4) من المادة نفسها من القانون المذكور (تكون قرارات بحلس الانضباط العام ملزمة

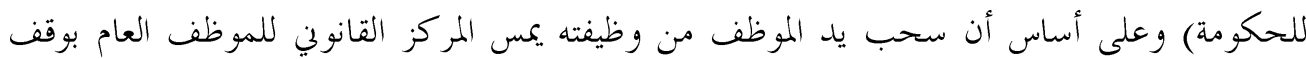
نصف راتبه و.... أي ان سحب يد الموظف يمس معظم الحقوق التي ينظمها قانون الخدمة المدنية(18).

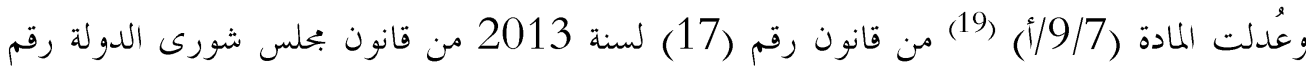

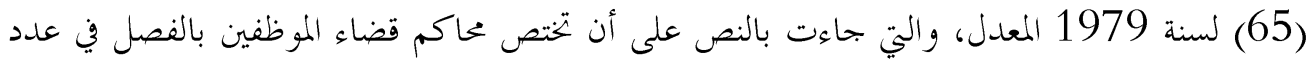
من المسائل ومنها "1-النظر في الدعاوى التي يقيمها الموظف على دوائر الدولة والقطاع العام في الحقوق 
الناشئة عن قانون الخددمة المدنية أو القوانين أو الأنظمة التي تحكم العلاقة بين الموظف العام وبين الجهة

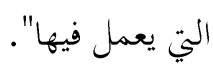
يلاحظ أن القانون المشار إليه قد شكل محاكم خاصة لحل الخلاف الذي يقع ما بين الموظف ودائرته وهذه المحاكم تسمى (بالمحاكم الإدارية) وتستطيع الغاء أي قرار اداري يكون مخالف للقانون أو قد إند

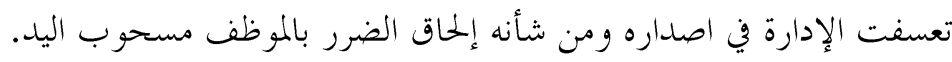

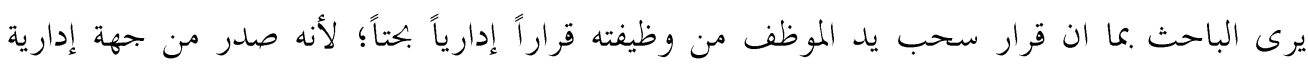

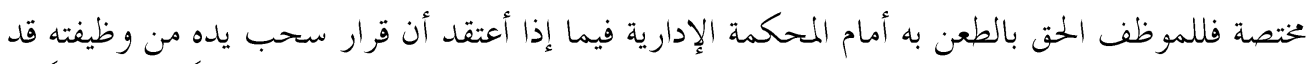

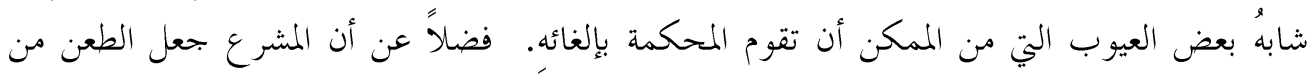

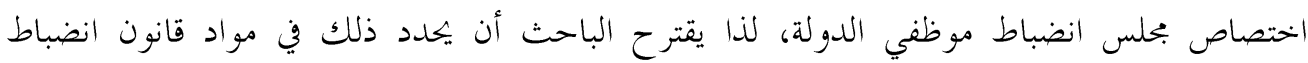
موظفي الدولة بنص صريح.

الفرع الثابي: الجهة المختصة في نظر الطعن بقرار وقف الموظف عن العمل في القانون الأردلين

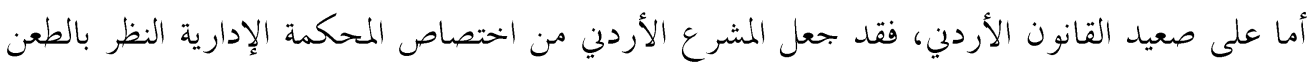

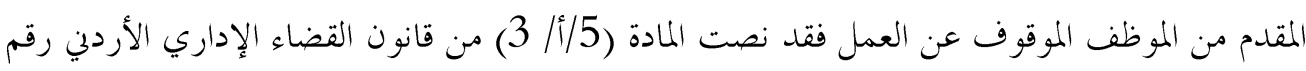
(27) لسنة 2014: (تختص المحكمة الإدارية دون غيرها بالنظر في جميع الطعون المتعلقة بالقرارات الإدارية النهائية بما في ذلك: طعون الموظفين العمومين المتعلقة بإلغاء القرارات الإدارية النهائية المتعلقة بأهاء خحماهم أو ايقافهم عن العمل)(20). لا يعد قرار ايقاف الموظف عن العمل عملاً مادياً(21)، كما لا يعد عملاً من أعمال السيادة التي لا تقبل الطعن بالإلغاء، بل هو قرار من القرارات الادارية التي تخضع لرقابة القضاء (22)، وبناءً على ذلك ألكال أجاز المشرع الأردني للموظف العام الذي يوقف عن العمل بالطعن بالقرار الإداري الصادر بالإرادة المنغردة من جهة الإدارة بإيقافه عن العمل أمام المحكمة الإدارية.

المطلب الثالي: جزاء عدم مشروعية قرار سحب يد الموظف العام من وظيفته

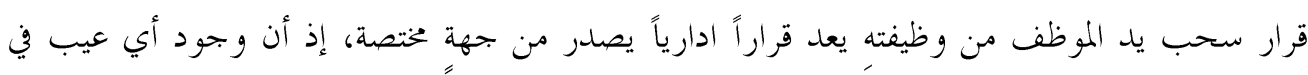

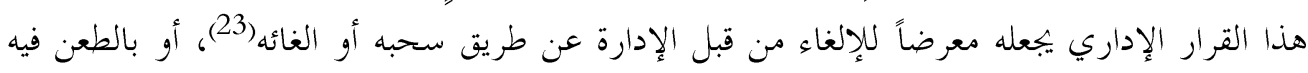

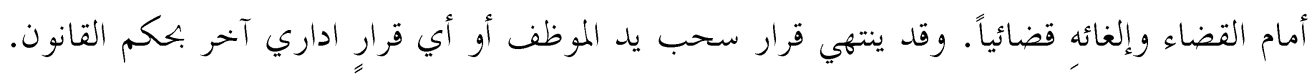

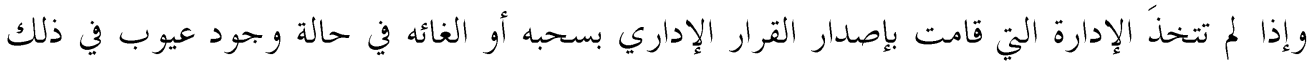


القرار بعد تظلم الموظف مسحوب اليد من وظيفته، فله الحق باللجوء إلى القضاء لغرض الغاء القرار

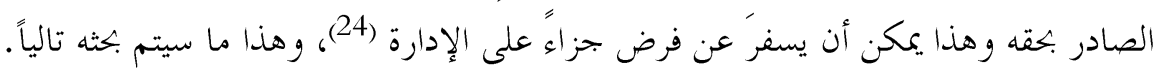

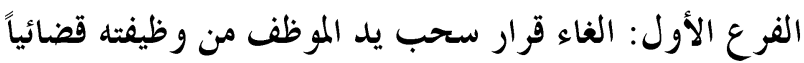

الضمانة القضائية هي أفضل الضمانات للموظف، وينبع ذلك من استقلال القضاء، ويعد اللجوء له الملاذاذ الآمن خاصة في حال عدم استجابة الإدارة لتظلمه حول القرار الإداري. وتبقى الضمانة القضائية التي لا لا

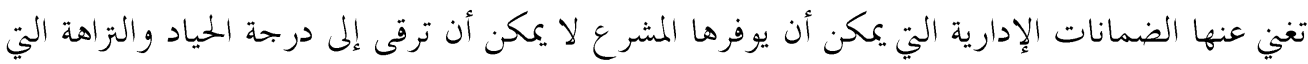
يمكن أن تتوفر عن طريق الطعن القضائي(25). فإذا وجدا عيب في القرار الإداري من قبل الجهة المختصة بالطعن في هذا القرار فتصدر حكمها بإلغاء هذا القرار ويكون الإلغاء بأثر رجعي من تاريخ صدور القرار الصادر من جهة الإدارة. وكما لم يكن فئن القرار قد صدر ابتداء، وبذلك يشبه الإلغاء القضائي للقرار الاداري سحبه من قبل الإدارة. ويحوز حكم الإلغاء حجية مطلقة في مواجهة أطراف الدعوى ومواجهة الكافة (26). وبناء" على ما تقدم فإن الإلغاء القضائي للقرار الإداري الصادر من جهة الإدارة يعد ملغياً و كأنه لم يكن،

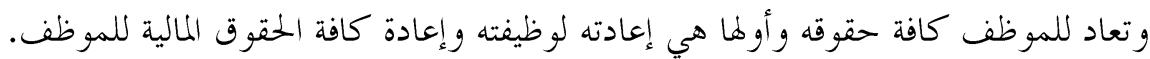

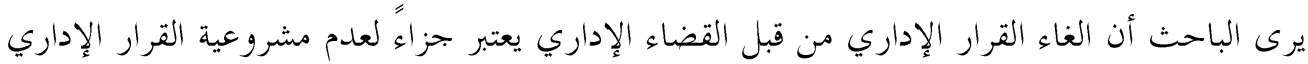

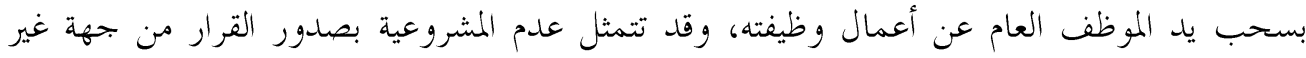

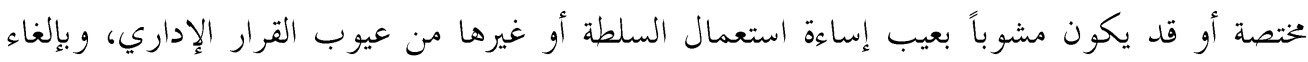
هذا القرار من قبل القضاء الإداري فإنه الآثار التي ترتبت عليه ستلغى وبالتالي سيستعيد الموظف العام حقوقه التي تأثرت بقرار سحب اليد من الوظيفة العامةً.

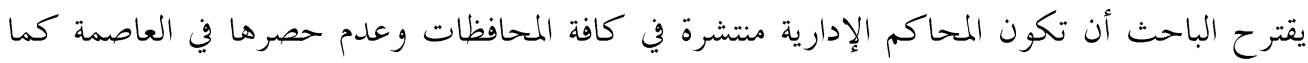

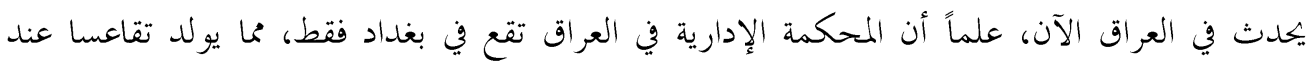

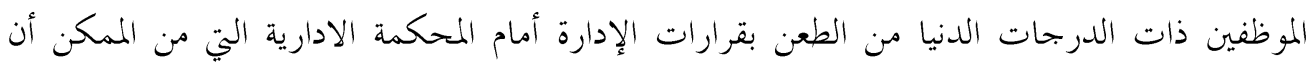
تكون غير مشروعة.

\section{الفرع الثابي: الحق في التعويض عن قرار سحب اليد غير المثروع.}

إن القرار الإداري السليم الصادر من الإدارة بحق الموظف لا يجوز المطالبة بالتعويض عنه في القانون

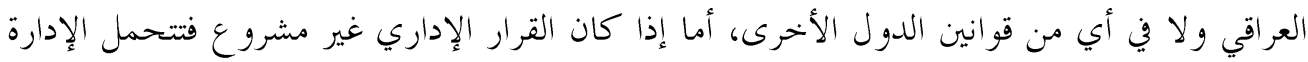


مسؤولية قرارها الذي أصدرتهُ إذا ثبت عدم مشروعية القرار وترتب عليه ضرر لحق بالموظف من جراء ذلك القرار.

و بناءً على ذلك يكون هنالك ارتباط وثيق بين الإلغاء والتعو يض بمعنى إذا رَفضت المحكمة دعوى الإلغاء

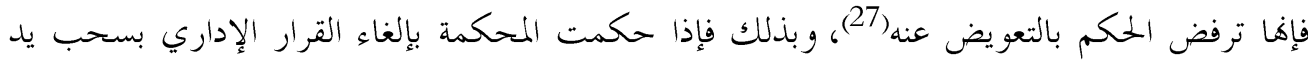

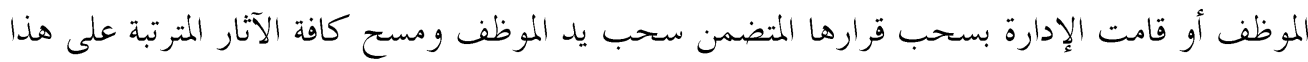

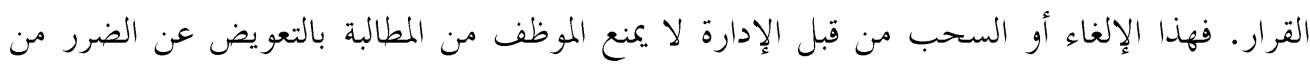
جراء القرار الإداري غير مشروع. من خلال البحث ومن خلال وظيفتي الادارية لم نعثر على أي قرار صادر عن القضاء الإداري العراقي

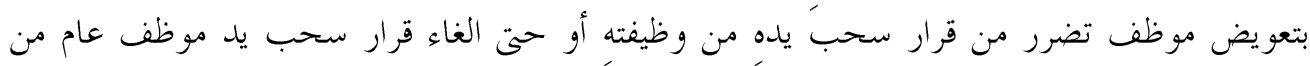
الوظيفة العامة.

يرى الباحث أن ذلك يعزو لعدم وجود المعرفة القانو نية لدى أغلب الموظفين أو بسبب طول المدد التي تتطلبها الإجراءات القضائية التي ربما تدفع الموظف لتجنب المطالبة بالتعويض وكذلك بسبب أو لبعد

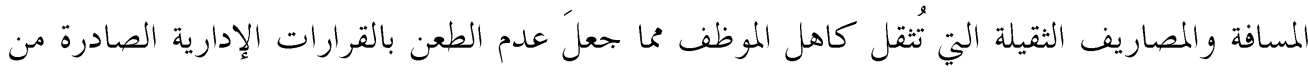

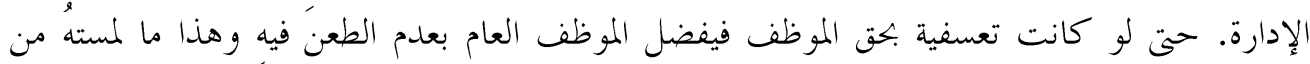

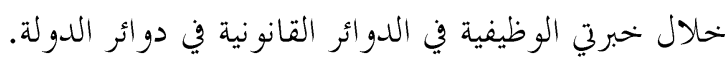
يلاحظ أن المشرع الأردبن قد أجاز للموظف الطعن في القرار الإداري الصادر بحقه من الإدارة أمام المحكمة الإدارية والمطالبة بإلغاء قرار الوقف عن العمل وذلك وفقاً للمادة (5/أ) من قانون القضاء الإداري، وكذلك المطالبة بالتعويض عن الضرر الذي لحق به بسبب القرار الإداري غير المشروع، وقد

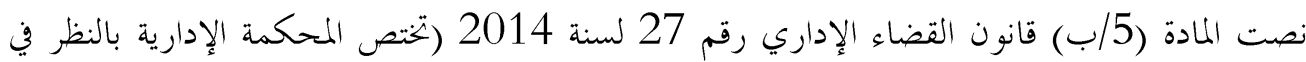
طلبات التعويض عن الاضرار اللاحقة نتيجة القرارات والإجراءات المنصوص عليها في الفقرة (أ) من هذه المادة إذا رفعت اليها تبعا لدعوى الإلغاء).

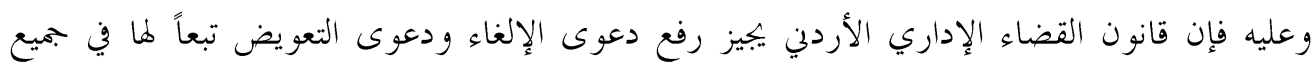

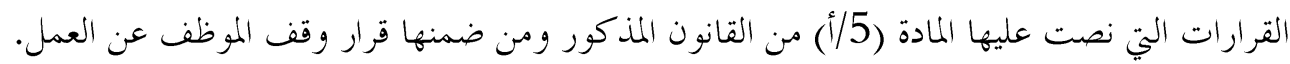

الحخائة:

جاء هذا البحث همدف الاجابة على اشكالية في غاية الاهمية هي ما مدى كفاية التنظيم القانوني لأسباب

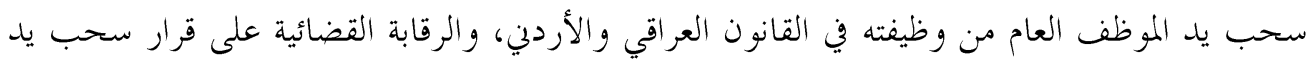


الموظف من وظيفته. و لان بقاء الموظف في وظيفته يثير شكوك حوله. و ان اجراء سحب يد الموظف هو اجراء مناسب لغرض ابعاده عن وظيفته اثناء التحقيق. قسم بكثنا إلى مبحثين رئيسين المبحث الأول يتناول أسباب سحب يد الموظف العام من وظيفته، أما المبحث الثاني فإنه يوضح الرقابة القضائية على قرار الادارة بسحب يد الموظف العام من وظيفته. وقد توصل البحث إلى بحموعة من النتائج و التوصيات، وهي كالآتي:

النتائج

1- عدم السماح للإدارة في القانون العراقي او الاردني باتخاذ اي اجراء قانوني ضد الموظف العام الا وفق الاصول القانونية المرسومة هلا من قبل القانون.

2- لا يجوز سحب يد الموظف من وظيفته الا نتيجة ارتكابه مخالفة مسلكية تتم من خلالفا احالته على المجلس التأديي او ارتكابه جناية او جنحة مخلة الشرف تتم من خلالها احالته الى المحاكم المختصة.

3- بين لنا من خلال البحث ان الضمانة القضائية هي من أفضل الضمانات لحماية الموظف من تعسف الادارة في اتخاذ القرارات الادارية بحقه.

\section{التوصيات:}

1- التشديد على تحديد حالات سحب يد الموظف من وظيفته كي لا تتعسف الادارة في سحب يد الموظف من وظيفته.

2- التشديد على ان يكون الطعن بالقرارات الادارية طعنا وجوبيا امام القضاء الاداري. خوفا من تعسف الادارة في قرار سحب اليد وتوجيه عقوبة تضر بالموظف وعائلته وخحاصة عقوبة العزل الفصل التي تضر بالموظف وعائلته.

3- خضوع كافة القرارات الادارية المتخذة بكق الموظف بسحب يلده من وظيفته للقضاء الاداري وان تكون هذه القرارات صدرت من جهة ذات اختصاص خولها القانون في اصدار مثل تلك القرارات. 
4. مصطفى محمد محمود، شرح قانون العقوبات القسم العام، القاهرة، دار النهضة العربية، 1983. 5.

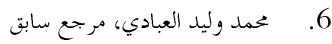

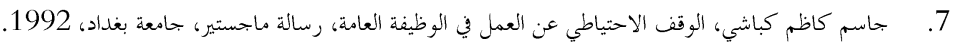

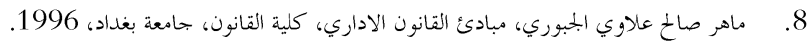

9.

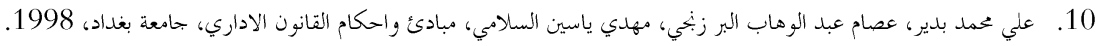

11. مهدي حمدي مهدي الزهيري، كلية القانون، جامعة حياة خاصة للعلوم والتكنلوجيا، بحث، كلية القانون والعلوم السياسية، المجلد السادس، الماني،

العدد الاول، 2017. 2017.

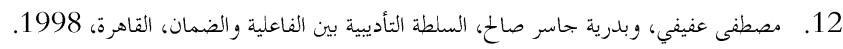

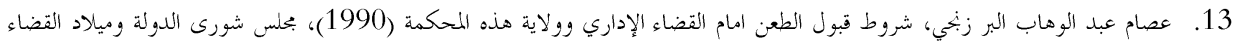

الإداري، بحثان منشوران في بحلة العلوم القانونية، العددان الأول والثان الثاني.

14. صالح إبراهيم المتيوني، شروط الطعن امام محكمة القضاء الإداري، رسالة ماجستير، كلية القانون، جامعة بغداد، 1994.

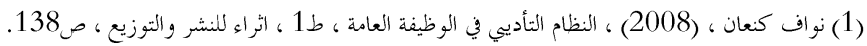

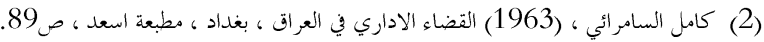

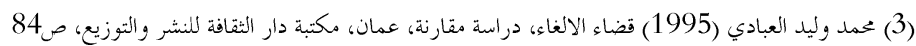

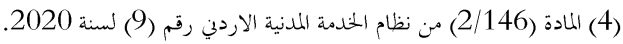

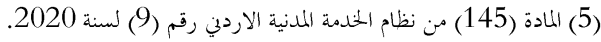

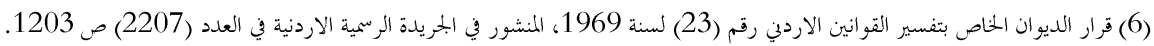

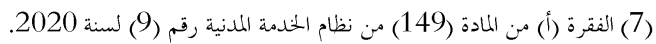

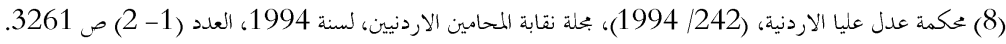

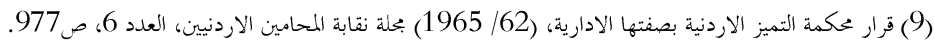

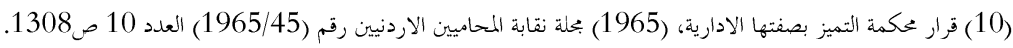

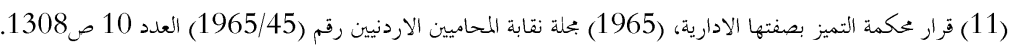

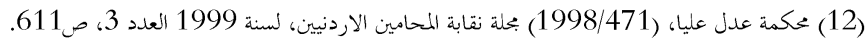

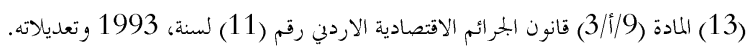

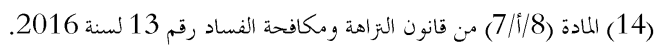

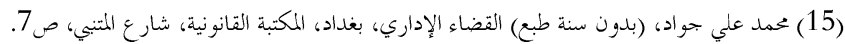

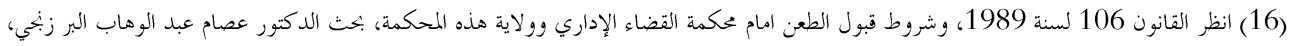

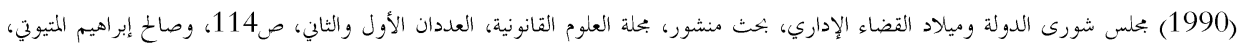

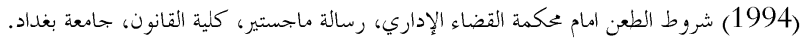

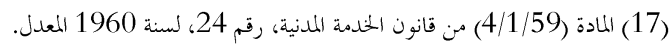

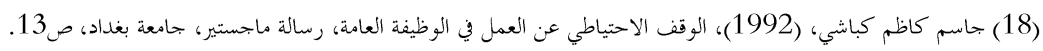

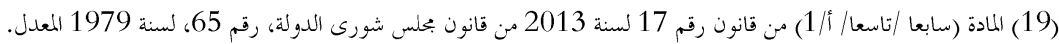

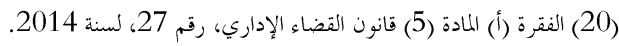

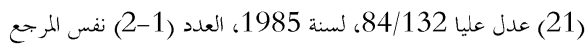
(22) حممد وليد العبادي، (1995) قضاء الالغاء، دراسة مقارنة، ط1 132، عمان الاردن، مكتبة دار الثقافة للنشر والتوزيع، ص84 العاع 


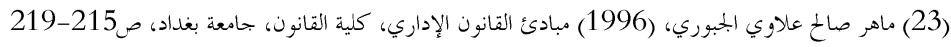

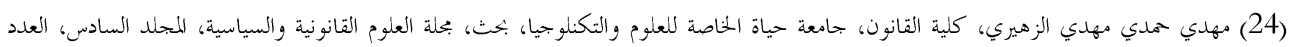

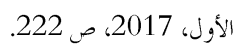

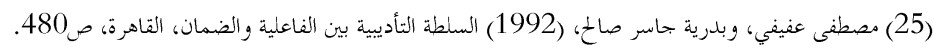

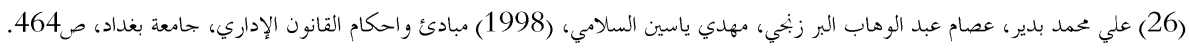

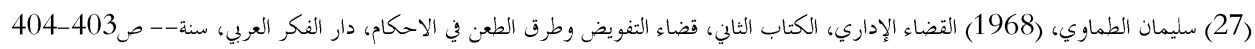

